\title{
Reflective Practice: Connecting Assessment and Socio-Legal Research in
}

\section{Clinical Legal Education}

\section{Cecilia Blengino, Università di Torino, Italy}

Susan L. Brooks, Drexel University, US

Marie Deramat, Universitè de Bordeaux, France

Silvia Mondino, Università di Torino, Italy

\section{Introduction}

Reflective practice represents a core feature of Clinical Legal Education (CLE) and has been one of CLE's most important and innovative contributions to legal education. The importance of reflective practice tools in teaching and assessing student learning is well known among clinical legal educators. Nevertheless, this field has not fully explored the ways in which reflective practice allows students to investigate legal proceedings and other aspects of law and legal processes. Without this research-oriented focus on reflection, clinical legal education risks being reduced solely to skills acquisition, and therefore failing to realize its potential as a vehicle for meaningful and positive social change. Focusing on investigating these broader social and institutional dimensions of reflective practice can greatly enrich the ability of legal clinics simultaneously to provide a laboratory for learning law in action, a fertile ground for research, and an instrument for the promotion of rights. Yet another dimension of this exploration is the opportunity for clinical law teachers to 
evaluate our teaching effectiveness and gain insights into ourselves and our immediate and long-term professional goals.

This paper shares some initial attempts to investigate the socio-legal dimensions of reflective practice in a sampling of clinical programs across several jurisdictions in Europe and elsewhere. These preliminary findings were presented at the most recent ENCLE Conference, which took place in Turin, Italy in September of 2018. For some time now, our 'transnational team' --comprised of clinical teachers from US, France, Spain and Italy ${ }^{1}$-has been exploring ${ }^{2}$ our common interest in researching the multiple roles reflective writing can play as a tool for assessing student learning and as an instrument for socio-legal research. During the session, the team members who were present shared and discussed some possible uses of reflective writing of various sorts, identifying their impact on learning, teaching, and research. This line of inquiry can potentially assist the clinical legal education community to reflect about the reasons for choosing particular tools for reflective practice in our clinical programs. Discussion and feedback from participants contributed important input to deepen our exploration and will assist us in developing further theoretical understandings in the future.

\footnotetext{
1 This work is the outcome of the sharing among professor from different countries: Susan L. Brooks (Drexel University Kline School of Law, US), J osè Antonio Garcia (Universitat the Valencia, ES), Cecilia Blengino (Università di Torino, IT), Silvia Mondino (Università di Torino, IT) and Marie Deramat (Universitè de Bordeaux, FR). We presented the session Reflective Practice: Connecting Assessment and Socio-Legal Research in Clinical Legal Education at the 6Th ENCLE Conference "Clinical Legal Education: Innovating Legal Education In Europe" held in Turin (Italy), 20-21th September 2018. The paper is the result of shared reflections inside our team. Only in organizing writing, Cecilia Blengino wrote the Introduction and par.1; Susan L. Brooks wrote par. 2.1; Cecilia Blengino and Silvia Mondino wrote par. 2.2; Marie Deramat wrote par. 2.3; Silvia Mondino wrote par. 3; Susan L. Brooks and Cecilia Blengino wrote par. 4. Conclusions are written by Susan L. Brooks.

2 This collaboration originated through exchanges during various international clinical legal education-related meetings and workshops over the past several years, such as the ones organized by ENCLE and GAJE.
} 


\section{Reflective practice and the epistemology of practice}

Reflective practice can be defined as method that helps individuals and groups think intentionally and systematically about their experiences and actions in order to engage in a process of continuous learning. Clinical legal educators view reflective practice "as fundamental to effective lawyering and the professional identity formation of lawyers, including the pursuit of core values, social justice, and personal growth" (Balsam et al. 2017-18, p.46). Reflective practice undoubtedly is more established and well-accepted in U.S. clinical legal education than in European legal clinics. In the European context, clinicians need to continue their efforts to expand awareness as well as deepen their understanding and further develop the meanings of reflective practice. While our group reflects a range of different contexts and also levels of experience in clinical legal education, most importantly, we share a common socio-legal framework. That theoretical perspective has led us to highlight the crucial role played by reflective practice tools and methods, which can help improve how we and our colleagues teach critical thinking and can support our efforts to overcome a legal positivistic approach to the law.

The role of reflective practice is often connected to the assessment of student learning processes by their teachers. This focus undoubtedly promotes the objectives of improving both teachers' evaluations of students and students' self-evaluations. Further, given that learning is a "the process whereby knowledge is created through the transformation of experience" 
(Kolb, 1984, p. 38), it is easy to understand how reflective practice can also dramatically amplify the capability of CLE to provide an alternative to the somewhat dogmatic and artificial attitude toward legal education that unfortunately still prevails in many law faculties, especially in Continental Europe. Operating in a real-world context, clinical legal education allows teachers and students to understand and to experience the great extent to which the exercise of rights is linked to praxis in the daily interpretation of the law, as well as cultural, economic, and social variables.

With respect to learning, reflective writing allows students to understand the gap between law in the books and law in action. It also provides a meaningful opportunity for students to evaluate themselves ex post. With respect to teaching, journals and other reflective writing represent a tool to assess our teaching methods and our ability to achieve our teaching goals. With respect to research, reflective journals and other reflective writing represent a kind of analytical auto-ethnography that permit faculty to discover new roads of research using a grounded theory approach. In this way students can become part of the research enterprise.

Far from being solely a way of introducing practical concerns into legal studies, clinical legal education represents a real-time laboratory for active learning. The integration of clinical training into students' legal education enables them to take an active role in their learning through a process of reflection on the process itself (Garcia Anon, 2014, p. 158). In this sense, we can approach the clinical experience as a socio-legal epistemology of law in action, where we recognize the distinctness of theory and practice while conceiving law as a phenomenon 
which is revealed through practice (Perelman, 2014, p. 133 ff.; Brooks \& Madden, 2011-12). As stated by Kruse, clinicians "are naturally situated to answer the call for embedded research, which fits closely with [the] social justice goals and reflective practice methods..." (Kruse, 2011-12, p. 298). In fact, situating students "in the heart of law in action" places them in circumstances in which they "daily encounter the gaps between what the law says, what it aspires to be, and what legal officials actually do, and are therefore poised to engage questions about the role of law in society." (Kruse, 2011-2012, p. 317-318).

In the field of legal studies, reflective practice thus represents a powerful "antidote to the technical/positivist nature of legal education" (Evans et al., 2017, p. 162), because of its capability to respond both to the need to improve students' critical thinking and to orient our work toward the application of social research methods. A number of scholars have offered different articulations of this approach, including considering critical reflection itself as a research method (Fook, 2011), emphasizing that reflective practice introduces action research into the study of law (Lewin 1946, Leicht and Day, 2000) and noting that reflective practice offers the chance for a study of law based on grounded theory (Glaser and Strauss, 1967; Charmaz and Briant, 2007).

Reflective practice enhances our awareness of learning as a socially situated iterative process. As pointed out by Donald Schön, "[e]veryday problems... are not simply pre-defined, but are constructed through our engagement with the 'intermediate zone of practice,' which, typically, is characterized by uncertainty, uniqueness, and value conflict." (Schön, 1983, p. 6). Moreover, 
reflective practice is a collective process that involves both students and teachers who become inquirers into their own practices (Leicht and Day, 2000, p. 183) and therefore have the opportunity to interrogate the legal issues they face from a socio-legal perspective. Through the use of reflective practice tools, such as reflective diaries and reports, teachers can identify and assess what their students have learned, and also can use their students' reflections to guide their planning toward future teaching efforts. Students also benefit directly from this process because reflective practice enriches their attitude towards deep learning

To underline the relevance of using the tools offered by reflective practice in understanding law, we note the distinction between reflection in action and reflection on action theorized by Donald Schön. Reflection in action is a process that occurs simultaneously with the legal practitioner's actual conduct, while reflection on action is a process that occurs after the conduct has taken place. As Schon articulated through his epistemology of practice, the professional nucleus of the reflective practitioner is formed by these two distinct processes: reflection in action and reflection on action (1983, p. 49).

Reflection in action takes place through quick processing and its accompanying actions. Given that reflection-in-action requires a high level of self-awareness and ingrained habits of reflection, we believe the clinical experience offers meaningful opportunities to improve students' capability to begin to develop this skill set by making decisions and resolving issues in real time. Creating the conditions to support students in cultivating this form of 
reflective practice is all the more critical because reflection in action by definition remains largely unconscious. Reflective practice helps to support reflection in action through reflection on action, that is, a systematic and documented reflection after events have taken place, involving reviewing conduct with the aim to identify strengths and challenges, and consequently to develop different options for future conduct...Reflection on action enables recognition of the paradigms that shape our thinking and action, made up of all of our implicit assumptions, frameworks, and patterns of thought and behavior. Reflective practice facilitates the deconstruction of these component assumptions, allowing students as reflective practitioners - to assess critically their own conduct, analyze, and inform their future practices, and ultimately, to contribute positively to their developing professional identities.

\section{How do we use reflective practice in our legal clinics?}

\section{1. Experience and aims at Drexel University}

We teach reflective practice in our clinical program in two distinct ways. First, each of the clinical faculty members teaches reflective practice with their own groups of (usually eight) students as a part of their day-to-day supervision of the students and also within a small group seminar format. The teaching of reflective practice at this level would resemble many law school based legal clinics across the U.S. and in many parts of the world. 
A second, perhaps more unusual and distinctive forum for teaching reflective practice is what we call the Justice Lawyering Seminar (JLS), which is a course in which all of our clinic students are enrolled together. Unlike the individual clinic seminars, in which a portion of the classroom time would likely be devoted to didactic teaching of the substantive law and practice skills related to the clinic's subject matter, JLS is devoted entirely to the goal of teaching reflective practice.

The topics typically covered in JLS include: considering questions such as 'who is the client?' and 'what is our role,' engaging clients effectively, navigating cultural difference, discussing making mistakes and other ethical concerns, exploring work/life balance and wellbeing, identifying different models of lawyering, and defining access to justice. Usually also there is also some form of "case rounds," with the important caveat that students can only discuss clients and cases without identifying or private information being shared, as they are not part of the same law firm.

The main reflective writing in the course consists of two graded "reflective analysis" essays, as we now refer to them. We have been using the term reflective analysis for several years (adopted from non-law school colleagues on campus), to emphasize the critical reflection component of these papers and the idea that this is serious work and is part of building a skill set that is as essential to effective lawyering as understanding legal doctrine, reasoning, and analysis. The detailed description of the reflective analysis assignments and assessment rubric is attached as Appendix I. 
The first of the two papers is modeled after a well-known type of assignment given to medical students called a "critical incident report." Students are asked to identify a particular situation or relationship that they have experienced as deeply challenging and disorienting, and to use it as the basis for their reflective analysis. The assignment contains a series of prompts, including:

- Identify a critical incident;

- Interpret it from multiple perspectives;

- Evaluate and explain its impact on you;

- Evaluate and appraise how you dealt with it;

- Examine, assess, and evaluate what you have learned from the incident; and

- Formulate and defend a plan of how you will approach similar incidents in the future.

The purpose of using this detailed structure is to give the students a template for doing reflective analysis that they can carry forward into a second, more openly structured reflective analysis paper. In the most recent version of this assignment, we specifically asked the students to reflect on the integration of personal, interpersonal, and systemic/social dimensions of what they have identified as a challenging situation or relationship. This prompt is an effort to help students 'connect the dots' between and among their own microlevel experiences and macro-level concerns related to access to justice and social justice more broadly, or as it has been articulated earlier in this paper, "to understand and to experience 
the great extent to which the exercise of rights is linked to praxis in the daily interpretation of the law, as well as cultural, economic, and social variables."

With respect to assessment of the students' reflective writing, two key criteria that have surfaced are their demonstration of their ability to question their own judgments and assumptions, and also demonstration of their ability to view a situation from multiple perspectives. These two as well as other important criteria are included in a rubric that is shared and discussed with the students in advance. They also have the opportunity to receive and to process written feedback they receive on their first paper prior to the deadline for submitting the second paper.

\subsection{Experience and aims at Bordeaux University}

Reflective practice has always been integrated into the live client law clinic in Bordeaux University, although our methodology has deeply progressed since 2013, when our live client clinic opened its doors. At first, we integrated post-interview debriefing with each team of students to exchange feedback with them about their experiences. This exchange provided a first moment of reflexive practice, essentially on their professional practice and position in relation to others persons. It also offered a place and space for other expressions, for example releasing tensions and working on team conflicts. We decided, however, that we did not have sufficient time to exchange feedback with our students on the social or systemic aspects of cases they dealt with in the law clinic. In particular, all of the discussions 
were focused on the immediate legal solutions rather than on other important issues that could be identified from these cases or on fundamentally questioning the law regarding its functioning, its impact, its core institutions and processes. As a result of these concerns, we decided to create a separate course devoted to reflective practice for participants in the law clinic.

Currently we have developed a specific course on reflective practice to integrate simultaneously the self-reflective practice aspect and reflection on rights. First, each student team is asked to work on an analysis of its legal aid case, explaining its interest at different levels: legal, sociological, socio-economic, human, and the difficulties the team has encountered during the experience. Based on whatever may be happening in the present moment, the teams are also asked to present a rapid response plan on how to deepen this case, including outside resources to contact to learn more about it. All students participate in a vote to select two cases for in-depth analysis. Seminars are then organized by the students on the selected cases, including inviting other actors to discuss them as well. It is important to note that the actors include professionals from other disciplines as well as legal professionals. The course ends with each team writing a report called "Beyond the Case." The teams are expected to discuss the implications of the law in an inter-disciplinary analysis and to identify possible changes. One part of the report is a personal reflective report, describing and analyzing one personal aspect of their experience (Appendix II). They are expected to determine the competencies they have acquired at that point as well as ones 
they need to improve. This report forms the basis for the final evaluation of the law clinic students.

\subsection{Experience and aims at the University of Turin}

In the legal clinics on prisoners and human trafficking, both of which are run by the University of Turin, we view reflective practice tools as essential for students' learning and other activities. The clinic on prisoners allows students to conduct interviews with people who are incarcerated inside the prison, which is a very particular and closed context (Goffman, 1968). In this clinic, students assist the prisoners' local ombudsmen in carrying out their institutional function of interviewing prisoners. The clinical law teacher is not always able to be present and observe the specific interview dynamics, and therefore it is critically important to create an effective tool for supervision. The legal clinic for victims in human trafficking presents some similar conditions, since students work at the sites of nongovernmental organizations (NGOs) and local institutions assisting their staff in interviewing victims/survivors. In both situations one of the most challenging aspects of the clinical activity is how the presence or absence of the teacher during the interviews of vulnerable subjects is received by the students. It is also important to define the way in which to supervise the students during the activities carried out in the absence of the teacher at the prison or NGO. 
In responding to these different situations, the clinical faculty has a common focus on close supervision of the students' experience. In the context of the prisoners' clinic, a grid of questions is given to the students before their first visit to the prison (Appendix III). The questions posed on this form help direct the students' attention to what to observe. In this way the students are not overwhelmed by the wide range of stimuli and are able to concentrate on issues considered central by the teacher. The grid of questions for the students working in the prison is extremely useful because it allows them to pay attention to the individual roles of the different subjects connected to the legal field, which helps them to grasp the relational dynamics. Once the visit is done, the teachers ask the students to fill out the form and submit it within a few days, to avoid the loss of important information. The students' responses are discussed together with the teachers and an expert criminologist in a subsequent meeting at the university, highlighting and addressing salient and recurring issues.

The grids provided in advance of the visits are oriented toward the students' own empirical research, guiding them in paying attention to important aspects of a local penitentiary especially during their first entry into the prison where they will be working. In addition to the grids, students also complete reflective practice reports (Appendix IV). The reports are additional reflective practice tools that are used to supervise the activities of the students working in the prison, governmental institutions, or NGOs in the absence of their clinical teachers. Throughout the time students are participating in a clinic, they are asked to reflect systematically on what they have encountered. The reports thus guide our students in 
addressing the tasks they have been given more effectively in a problem solving direction. We have found that encouraging our students to divide the situations they face into conceptual and chronologically related segments helps them to deepen their ability to learn from those situations and also actively to find ways to resolve challenging tasks. The reports thus serve to improve students' critical thinking as well as being used as instruments for the teacher to supervise their work.

Gaining confidence with these tools has not been not easy for our students, who initially perceived them mostly as a way to communicate their emotions and in particular their discomfort to the teacher, rather than as an opportunity to rethink what they had done during the meeting with the client. In response to this situation, we decided to combine all the reports from the first meetings and offer our comments together with the entire group of clinic students. By reading them in class we have encouraged students to try to deepen their insights into the potential reasons for their perceptions of powerlessness, discomfort, etc., with the added value of peer sharing. It is important to emphasize that the role of the clinical faculty in this classroom discussion is distinct from that of psychologists or psychotherapists. For instance, when a given operator seems to refuse the students' offer of collaboration, and this situation gives rise to the students' feeling of powerlessness, the teachers have the students consider the range of potential reasons that person may have acted in that manner, including how he interprets his role and which legal resources could be useful to him. The teachers' response is therefore engaging the students in reflective practice rather than offering psychological counseling or psychotherapy. Following such a 
classroom discussion, an approach that works very well is inviting students to revisit their original responses to the questions, highlighting the parts they were able to reflect on with new perspectives.

In general, the working method in this clinic is based on a first step of guided observation of the context, analysis, and description, followed by shared feedback and reflection, and then new analysis. The initial objective of the reflective practice reports was to have a tool to surface the legal questions from the students' meetings with those seeking legal assistance, that is, helping the students identify the elements that needed to be considered from a legal point of view and also those that needed to be set aside or referred to other professionals. At the same time, the reports served to reassure the students during the practical activity, knowing that they could address and receive guidance from the teachers through the reports. In time, what emerged very clearly was that the reflective reports could be used to highlight the dynamics of power between the various actors and, above all, to analyze the gap between law in action and law in the books.

Through careful analysis of a significant number of reports, we have been able to draw further meaningful insights: the students' ability to gaze inside of some of these realities has allowed them to investigate "shadowing," thus highlighting some new lines of research through the grounded theory methodology. So the students have found themselves, almost by chance, to have a very useful tool also for socio-legal research. 


\section{Models for reflective practice reports}

During their activities the clinical students need to be encouraged to develop knowledge and skills that allow them to experiment in a certain field. And yet, they also need to be supported in that process. Reflective reports represent an important tool to help guide and direct students in their learning process. In this section, we consider four of the main models to promote reflective practice: (1) the Kolb cycle (1984); (2) the Gibbs cycle (1988): the Atkins and Murphy model (1993): and (4) the Mezirow model (2000). Using an actual situation that occurred during one of our clinic's activities as a sample may facilitate a richer understanding of these models, as well as their teaching aims and potential. The case deals with legal aid offered by law students to assist inmates. The clinical teachers proposed that some inmates who are also students--meaning they study law in that prison-- join the clinical students to carry out the consultancy activity. During this time it turned out that no other inmates ever showed up, and so the 'expert' inmates remained to talk with the students for three hours. The law students struggled a great deal with this situation and how to integrate it into their learning. For us as clinical teachers, it helped to highlight the point that we need to provide our students with more adequate tools to allow them to address issues and unpredictable events more effectively and to reflect on such situations in order to learn from them.

The Kolb Cycle (1984) proposes a four-point scheme: plan, do, reflect, and integrate lessons learned into future planning. First, a concrete situation needs to be planned, and second, 
experienced. Third, it is necessary to reflect on the experience, to try to extract the concepts and to learn from the experience. Finally, it is necessary to plan and bring out what has been learned. This model, which seems very simple, in reality requires from students a great deal of self-directedness in defining what has been learned. In an experience like the legal clinic where there are many and varied stimuli, this can be very complicated. Students can reflect on the experience using the Kolb cycle. However, they may interpret a situation like the one just described simplistically; based on that one instance, they may decide that the inmates do not really need a help desk in the prison to provide legal advice, and therefore, the clinic's resources could be better utilized elsewhere.

The Gibbs model (1984) presents six precise questions that specify a very clear path for reflection, and may help the students to deepen their reflective capacities so they can go beyond their initial impressions. Students are asked to answer to the following questions:

(1) Description: What happened? What, where, and when? Who did/said what? What did you do/read/see hear? In what order did things happen? What were the circumstances? What were you responsible for?

(2) Feelings: What were you thinking about? What was your initial gut reaction, and what does this tell you? Did your feelings change? What were you thinking?

(3) Evaluation: What was good or bad about the experience? What pleased, interested or was important to you? What difficulties were there? Who/what was unhelpful? Why? What needs improvement? 
(4) Analysis: What sense can you make of the situation? Compare theory and practice. What similarities or differences are there between this experience and other experiences? Think about what actually happened. What choices did you make and what effect did they have?

(5) Conclusion: What else could you have done? What have you learned for the future?

(6) Action Plan: What will you do next time? If a similar situation arose again, what would you do?

The advantage of this model is that it provides a structure for an "enactive" approach to teaching. Enactment theory is taken from the studies of Maturana and Varela (1984), who shift the idea of scientific research from strictly biological observations to concepts of value also other contexts of human life. In the foundations of this epistemological theory, P. G. Rossi (2011) recognizes and appropriately refers to the field of human learning and added concepts of embodied cognition, learning by doing, and research-based teaching, all of which form the basis for a new and more modern didactics. Rossi explains how the enactive model can be applied consistently to the teaching/learning relationship, considering all the agents, not individually, but rather in the structural whole they create by growing together. When contrasted with the constructivist approach to teaching, the main differences are related to enactivism's greater attention to the relationship between subject and environment rather than the structures within the individual, along with the use of the body, perception, gestures, empathy, and the use of technology. 
In the Gibbs model, peoples' gestures and sensations assume importance. In this sense it offers the opportunity to pay attention to the "third dimension" of the law"--the approach shared by "rebellious lawyers" (White, 1988, pp. 760-762) that emphasizes the need for "translating felt experience into understandings and actions that increase the power of vulnerable people." In this manner, the Gibbs model can help students compare law in action and law in the books. The students waiting for the inmates who didn't arrive at the counter experienced feelings of frustration. In evaluating the benefits and challenges of this experience, significant weight can be given to the unexpected extended interview of the "expert" inmates, who offered the law students their vision of important unmet needs within the prison. By analyzing the situation in this manner, students may well be able to recognize and value their experience differently, to the extent that that they have received important information that can be shared with the larger population of inmates and revisited with them during a future visit.

The Atkins and Murphy model (1993) proposes five steps for reflection:

(1) Become aware of discomfort, or action/experience;

(2) Describe the situation, including salient, feelings, thoughts, events, or features;

(3) Analyze feelings and knowledge. Identify and challenge assumptions. Imagine and explore alternatives;

(4) Evaluate the relevance of knowledge. Does it help to explain/resolve problems? How was your use of knowledge?

(5) Identify any learning that has occurred. 
With respect to this model, one of the central aspects is the attention to possible alternatives and the way in which to use one's own knowledge.

Turning back to our example, law students could use this model to analyze and reflect critically on their role and adapt their approach in order to take advantage of the changing situation. What emerged from the extended conversation with the student inmates was a strong concern about many difficulties connected to the path of exiting the prison and social reintegration. Through more conscious reflection using steps three through five of this model, the law students could shift their focus to working collaboratively with the student inmates to come up with ideas for addressing their concern about reintegration, drawing upon the legal knowledge of both groups

Finally the model of transformational learning of Mezirow (2000) offers additional guidance for improving clinic students' ability to engage in reflective practice. While the first steps of this model resemble the previous two models, it is distinctive in terms of its heightened focus on the moment of sharing, the potentially transformative nature of the process, the different roles and dynamics that can be imagined, and finally the ability to view the situation from a new and different perspective.

Returning to the example, by sharing and reflecting upon their immediate reactions, the students can identify their own progression, from the narrow lens through which they initially approached the situation and needs within the prison to their realization, reached 
through deeper engagement with the student inmates, that the help desk is not the appropriate resource to offer help with the challenges of reintegration. After then working to imagine different ways in which both groups could collaborate, beyond from those initially conceived, the students and student inmates have created a physical resource kit containing a set of materials in which there are essential tools (a bus ticket, a map, a list of dorms or places to have lunch for free) and also a virtual one in which there is legal information regarding issues to keep in mind for reintegration into communities. This information includes, for example, how to check that you still have certain benefits in place, how to find a residence, and how to find a doctor.

Reflective reports can be the tool for new projects, and also, most importantly, for new lines of research. Indeed, the analysis of situations, the dynamics between the different actors, and the gap between the law in action and the law in the books can lead to the development of new research questions. As a result clinical students can go beyond the traditional horizons of "pure research" and carry out research into the reality within which they are acting, which can also allow them to grasp the transformational nature of the process of knowledge and the potentially dynamic and reciprocal relationship between researchers and subjects.

\section{Reflective Practice in Action: feedback from our session using a case study}


We began the session by providing an overview of our shared socio-legal perspective regarding the significance and value of reflective practice in clinical legal education. Each presenter then briefly discussed the reflective teaching and assessment tools they use in their own clinical teaching context. Next, we engaged participants in a group discussion around the various opportunities and challenges offered by such educational tools using an actual case study from one of our clinics. For this purpose we chose a reflective writing report submitted by a student in the Turin Legal Clinic. In the report the student used the Gibbs model as a guide for reflection following an interview with a person who was seeking asylum as an alleged victim of human trafficking. Below we reproduce some excerpts of the student's report to demonstrate how it can be a helpful reflective practice tool, and also offer some of the feedback we received and our responses.

In the session we framed the discussion with the following questions for participants: What should or could be the goals of a reflective practice report following this type of interview? What elements of reflective practice arise from such a report? As teachers, what can we learn from such reports and how can we respond to deepen and develop our students' reflections?

In the case we examined, when asked about "what happened," a student wrote that: "...the second interview in preparation for the Territorial Commission [...] lasted about an hour and a half and we were present, my colleague, a Nigerian mediator and the legal operator. In the first part of the interview we explained again to the asylum seekers (then a.s.) what was said in the previous 
meeting about the committee hearing. She seemed more relaxed than the last time. The appearance. of the a.s. changed to the first "real" question about her past: she became visibly more insecure and agitated [...] The interview moves very slowly. The a.s. said several times "I do not know" [...]: once she was invited to deepen she didn't understand the question, sometimes told something more, while others explains "I can not remember, maybe next time I will succeed." She was nervous and cried several times. [...] She found herself in Libia, she was locked up in a prison where food and water were missing. Some of the other prisoners, both men and women, died. At one point she managed to free herself, but she couldn't remember".

Aside from stating what concretely happened, the structure of the report guides the student to identify the different legal actors who were present, and to describe the asylum seeker's emotions as they shifted during the interview. This student's entry thus offers the teacher a meaningful opportunity to improve the student's critical reflection on a number of levels. For instance, the teacher could highlight the gap between legal procedures in books and in action, by inviting the student to think more deeply about the roles the "Nigerian mediator" and the "legal operator" could play in preparing this asylum seeker for the hearing before the Territorial Commission. The teacher could also asking the student to reflect more on the emotions expressed by the asylum seeker and how the student responded to them, as well as the role emotions play in an interview of this nature and in asylum proceedings more generally. 
If this student had simply been asked to describe what happened, most likely he would have reported that the interview was unsuccessful, as it was not possible to collect all of the data needed by the clinic from the asylum seeker at this stage. Inviting the student to engage in a more systematic and careful review of the different aspects of he interview and the ways it took shape allowed the student to recognize key elements: the slowness of the meeting, the silence and the reticence of the asylum seeker, and her tears, all are potential indicators of being in front of a victim who still needs to be helped and removed from the influence of her enslaver, who may well still be nearby.

When asked about the evaluation, that is, what was good or bad about the experience? (What pleased, interested or was important to you? What difficulties were there? Who/what was unhelpful? Why? What needs improvement? The student response included the following reflection.

....Always at the end of the interview, we discussed the psychological status of the a.s. The operator was very confused, because she did not understand how afraid she was to tell certain things and / or great suffering in doing so. We talked about tears and what seemed to us a palpable suffering. Also in this case the mediator told us that tears can be fake and they do not have to be taken into consideration. Clearly, I do not want to question the work of a mediator who has been doing this work for years. In the specific case, however, they seemed counterproductive: more silences, more attention to the a.s. and even less "freedom" than the legal operator. Post-interview we were confronted with the legal operator on the role of the mediator and she was also perplexed about some choices made.... 
The importance of self-reflection emerges here from the capacity of this student to identify the key role played by emotions and other important "extra-legal" elements such as the client's suffering and her tears. Further the student has been able to bring a critical perspective to his analysis of this part of the legal proceeding, especially regarding of the capacity or incapacity of the operator to manage it and the "counterproductive" role assumed by the cultural mediator.

During the discussion that took place in our session, double-layered critical observations emerged. The structure and specific prompts in the report enable the student both to reflect on how useful an empathic approach could have been in this situation to support the client's ability to be more open in telling her story, and to reflect in depth on the gaps that the actions of certain actors, such as the mediator, demonstrate between legal procedures in the books and in action. From this perspective, students are simultaneously critically observing difficulties that have occurred in real time to inform their future actions, and they are also participating in a kind of empirical research on legal procedures and praxis.

It was clear during the discussion among participants that the use of this report offers a range of different stimuli for reflection, which can be collected by the teacher and can help shape future clinical teaching/learning objectives. The discussion served to highlight the multiple roles and meanings of reflective practice reports and the different aims they can serve for us as clinical legal educators as well as our students.

The teaching and learning objectives participants identified using the example presented during the session were wide ranging and featured the following: 
- Assessing the learning process;

- Involving students in the learning process;

- Reflecting on challenges posed by the law in action;

- Becoming more aware of justice issues and systemic issues; Reflecting on the lawyer's role.

Finally, a very interesting point shared among presenters and participants is the importance of being more transparent and explicit with our students about the roles and meanings of reflective practice. Nearly all of the presenters--even those of us who expressed confidence about the use of reflective practice in our clinics--admitted that we often use these tools for reflection in our students' learning process without explaining our full scope of our aims for using reflective practice, including its role as grounded research.

\section{Conclusions and next steps}

This collaboration has demonstrated the value of dialogue and sharing around reflective practice among clinical law teachers from different countries and contexts. All of us have gained new insights as well as new tools for teaching and assessing our students as reflective practitioners. We hope to continue this exploration together, particularly around how reflective practice can serve as a vehicle for socio-legal research. We invite our clinical colleagues and future readers to share their materials and case examples with us to deepen 
and enrich our collective understanding and to help us to make more of a positive difference in the lives of our students, our clinic clients, and the vulnerable communities we aim to serve. 


\section{References}

Atkins, T.W. and K. Murphy (1993). Reflection: a review of the literature, in Journal of Advanced Nursing, 18, 1188-92. https://doi.org/10.1046/j.1365-2648.1993.18081188.x.

Balsam, J. S., S. L. Brooks, and M. Reuter (2017-2018). “Assessing Law Students as Reflective Practitioners". In N.Y. L. Sch. L. Rev., 62, 49, p. 45-67.

https://brooklynworks.brooklaw.edu/cgi/viewcontent.cgi?article=1935\&context=faculty

Brooks, S.L. and Robert G. Madden (2011-2012). “Epistemology and Ethics in Relationship-

Centered Legal Education and Practice". In New York Law School Law Review, 56, p. 331-366.

Charmaz, K. and A. Bryant (2007). The Sage book of Grounded Theory, Sage, London. Dewey, J. (1933). How we think: a restatement of the relation of reflective thinking to the educative process, Revised edn.), Boston: D. C. Heath.

Evans, A., Cody A., Copeland A., Giddings J., Joy P., Noone M. A., and S. Rice (2017).

Reflective practice: The essence of clinical legal education in Australian Clinical Legal Education: Designing and Operating a Best Practice Clinical Program in an Australian Law School, p. 153-178.

Finlay L. (2008). Reflecting on 'Reflective practice', PBPL paper 52, www.open.ac.uk/pbpl. Fook, J. (2011). Developing critical reflection as a research method, in J. Higgs, A. Tichen A., Horsfall, D. and D. Bridges (ed), Creative Spaces for Qualitative Researching, Sense Publishers, Rotterdam, p. 55-64.

Glaser, B. G. and A. Strauss (1967). The Discovery of Grounded Theory, Aldine de Gruyter, New York. 
Gibbs, G. (1988). Learning by doing: A guide to Teaching and Learning Methods, FEU, Birmingham.

Kolb, D. A. (1984). Experiential Learning: Experience as the Source of Learning and Development. Englewood Cliffs, Prentice Hall, New York.

Kruse, K. (2011). “Getting Real About Legal Realism, New Legal Realism and Clinical Legal Education", in New York Law School Law Review, 56, p. 659684.https://open.mitchellhamline.edu/cgi/viewcontent.cgi?article=1383\&context=facsch.

Leitch, R. and C. Day (2000). “Action research and reflective practice: towards a holistic view", in Educational Action Research, 8, 1, p. 79-193.

Lewin, K. (1946). "Action Research and Minority Problems", in Journal of Social Issues, 2, p. $34-46$.

García-Añón, J. (2014). La integración de la educación jurídica clínica en el proceso formativo de los juristas" REDU. Revista de Docencia Universitaria, número extraordinario "Formación de los licenciados en Derecho", 12 (3),153-175.

Goffman, E. [1961] (2007). Asylums: Essays on the Social Situation of Mental Patients and Other Inmates, Routledge, London.

Maturana, H. and Varela F. (1984). El Arbol del conocimiento, (Organización de Estados Americanos, OEA.

Mezirow, J. (2000). Learning as transformation: Critical perspectives on a theory in progress. Jossey-Bass, San Francisco. 
Perelman, J. (2014). “Penser la pratique, théoriser le droit en action: des cliniques juridiques et des nouvelles frontières épistémologiques du droit", in Revue interdisciplinaire d'études juridiques 72, 2, p. 133-153. https://www.cairn.info/revue-interdisciplinaire-detudes-juridiques-2014-2-page-133.htm.

Rossi, P.G. (2011). Didattica enattiva. Complessità, teorie dell'azione, professionalità docente. Franco Angeli. Milano.

Schön, D. (1983). The reflective practitioner: how professional think in action. Temple Smith. London.

Spencer, R. (2012). “Holding up the Mirror: a theoretical and practical analysis of the role of reflection in clinical legal education", International Journal of Clinical Legal Education, Vol. 17-18, pp 181-217. http://dx.doi.org/10.19164/ijcle.v18i0.6.

White, L. (1988). To Learn and to Teach: Lessons from Dreifontein on Lawyering and Power, Wis. L. Rev, 699, pp.760-76. 
Appendix I. Assignments and Assessment (Justice Lawyering Seminar, Drexel University)

\section{Assignments and Assessment Materials-Spring 2018}

\section{Reflective Analysis Paper Guidelines and Evaluation Criteria:}

Each student is required to submit two (2) reflective analysis papers. The first paper is expected to be 2-4 pages in length, and the second paper is expected to be 3-5 pages. Each reflective analysis paper needs to be written in the form of a reflective essay, including various elements we will discuss in class. Students need to demonstrate the use of appropriate sources as well as the ability to question your own assumptions and explore an issue from different perspectives. In-depth research or extensive citations to sources are not required. Appropriate sources can include: course readings, TED talks, in-class and blog discussions, relevant outside sources, and anything connected to your pro bono placements and experiences.

\section{Paper \#1: Engagement with the Spheres of Transformation}

$>$ In this class, we are addressing three spheres of transformation: personal, interpersonal, and systemic. Identify a way you have engaged thus far in some level of a transformative experience connected to [at least] one of these three spheres. The basis for your reflection can include experiences in this class, your pro bono placement, your field observation, or in some other outside experience connected to or inspired by this class.

$>$ It may be transformative because:

- you learned something from it;

- it helped you identify an area of law where you now think you would like to work or not like to work;

- it helped you identify an aspect of law practice you now want to seek out or avoid;

- it led you to question important beliefs or assumptions;

- it excited you or surprised you;

- it has influenced you in some way;

$>$ Interpret the experience, taking into account the perspectives of everyone directly and indirectly affected by it.

Discuss how this experience has affected you at the personal, interpersonal, and systemic level, including some discussion of the particular sphere(s) of transformation involved.

Discuss how you dealt with the experience and how you are dealing with its effects on you.

Discuss what you've learned from the experience.

Formulate and discuss a plan for how you might approach similar experiences in the future. 
Appendix I. Assignments and Assessment (Justice Lawyering Seminar, Drexel University)

\section{Paper \#2: Reflective Analysis of a Topic of Your Choice}

\section{The following are some suggested topic areas:}

A reflective analysis of an ethical issue that has arisen within your placement.

A reflective analysis of an access to justice or law reform issue that has arisen within your placement.

A reflective analysis of a client related practice issue that arose within your placement.

A reflective analysis of a client interview.

A reflective analysis of your view of the role of lawyers in society in the context of your placement experience(s).

A reflective analysis of your personal goals for the class and/or your pro bono experience, and the extent to which you are achieving those goals, or perhaps have changed the goals as the semester has progressed..

The organization of your papers should generally include the following:

(a) a title and appropriate subheadings throughout

(b) an introductory paragraph or short section, which identifies the topic/issues, and any important themes. This section needs to inform the reader about what led you to want to discuss this topic;

(c) a background section, which provides the necessary groundwork or foundation for your exploration of the topic;

(d) a section in which you provide a detailed analysis of the theme/issue(s), including your own well-reasoned perspective or viewpoint. You can feel free to borrow ideas from others, with proper attribution, although this section needs to include your adaptation and integration of those ideas. In addition, it is important that you demonstrate your ability to question your own assumptions and to articulate and explain other perspectives, also with appropriate attribution. This section also needs to include issues or ideas you recognize are worthy of further exploration.

(e) a brief concluding paragraph, in which you highlight what you think are one or two of the most salient points and future-oriented ideas, and/or to suggest one or two broader implications of your analysis. These can be lingering questions or issues you intend to work on or explore further. 
Appendix I. Assignments and Assessment (Justice Lawyering Seminar, Drexel University)

\section{Assessment of Content of Reflective Analysis Papers ${ }^{1}$}

\section{Dimension 1: Clarity of the topic}

- Is it clear what triggered the reflection? What is the writer's dilemma or puzzle?

\section{Dimension 2: Consideration of Relevant Alternative Perspectives}

- Does the writer include all relevant perspectives, including his or her own?

- Are the perspectives justified by data?

- Are they explored in a way that promotes additional reflection?

\section{Dimension 3: Expressions of Engagement in Reflection}

- Is the writer engaging in deep, analytical reflection?

- Is there evidence of personal struggle on intellectual/cognitive and emotional levels?

- Is there evidence the writer is willing to question assumptions?

- Does the writer make it apparent how he or she came to choose the topic for reflection?

- What's at stake for the writer?

\section{Dimension 4: Lessons Learned}

- Is there an explicit statement of what was learned?

- Is there evidence of movement from previously held or deepening of beliefs?

- Is there a plan for action or a commitment toward personal or systemic change?

The overall criteria for evaluation/grading will be as follows:

(a) Organization (30\%)

-completeness

-flow/clarity

-presentation

(b) Content (60\%)

-articulation and analysis of themes

-depth of reflection and ability to integrate other perspectives

\footnotetext{
${ }^{1}$ Rachel Spencer, Holding Up the Mirror: A Theoretical and Practical Analysis of the Role of Reflection in Clinical Legal Education, 18 InT'L J. CliniCAL LEGAL Educ 181 (Appendix B, quoting Michael J. Devlin, Andrew Mutnick, Dorene Balmer \& Boyd F. Richards, Clerkship-Based Reflective Writing: A Rubric for Feedback, in MEDICAL EDUCATION 2010, 1117-1147, at 1143).
} 
Appendix I. Assignments and Assessment (Justice Lawyering Seminar, Drexel University)

-appropriateness and accuracy of references

-originality of thought and/or critique and adaptation

(c) Overall Impression (10\%)

-choice of topic

-timeliness, grammar, spelling, typos, etc.

\section{Assessment Continuum for Reflective Analysis Papers 2}

\begin{tabular}{|c|c|c|c|c|}
\hline & Describing & Understanding & Reflecting & Transforming \\
\hline $\begin{array}{l}\text { Nature of } \\
\text { the account }\end{array}$ & $\begin{array}{l}\text { Account is } \\
\text { descriptive, with } \\
\text { little or no } \\
\text { reflection. A story is } \\
\text { told, but mainly or } \\
\text { entirely from one } \\
\text { viewpoint. Ideas or } \\
\text { recollections of } \\
\text { events are linked by } \\
\text { sequence rather } \\
\text { than meaning. }\end{array}$ & $\begin{array}{l}\text { Account is } \\
\text { descriptive and } \\
\text { signals points for } \\
\text { possible reflection. } \\
\text { Events are treated as } \\
\text { though they might } \\
\text { raise an important } \\
\text { question or } \\
\text { questions to be } \\
\text { asked and } \\
\text { answered. There } \\
\text { may be reference to } \\
\text { another viewpoint. }\end{array}$ & $\begin{array}{l}\text { Account is } \\
\text { descriptive and } \\
\text { accents points for } \\
\text { actual reflection. } \\
\text { There are references } \\
\text { to other viewpoints } \\
\text { and external ideas, } \\
\text { and analysis of the } \\
\text { actions of self or } \\
\text { others. There is } \\
\text { some standing back } \\
\text { from events in an } \\
\text { effort to recognize } \\
\text { the effect of events } \\
\text { on the self. }\end{array}$ & $\begin{array}{l}\text { Description serves the } \\
\text { reflective process. } \\
\text { Account recognizes } \\
\text { that the frame of } \\
\text { reference for an event } \\
\text { can change. Events are } \\
\text { understood in a } \\
\text { historical, social or } \\
\text { psychological context } \\
\text { that influences } \\
\text { reactions to them-in } \\
\text { other words, multiple } \\
\text { viewpoints are } \\
\text { considered. }\end{array}$ \\
\hline $\begin{array}{l}\text { Emotional } \\
\text { reactions }\end{array}$ & $\begin{array}{l}\text { There are no } \\
\text { references to } \\
\text { emotional } \\
\text { reactions, or if } \\
\text { there are, they } \\
\text { do not get } \\
\text { explored or } \\
\text { related to } \\
\text { behavior of self } \\
\text { or others. }\end{array}$ & $\begin{array}{l}\text { Emotional } \\
\text { reactions of self or } \\
\text { others are } \\
\text { mentioned or } \\
\text { clearly influence } \\
\text { the writing. Such } \\
\text { influences are } \\
\text { noted and } \\
\text { questioned. }\end{array}$ & $\begin{array}{l}\text { Emotional reactions } \\
\text { are recognized and } \\
\text { their influence is } \\
\text { questioned. An } \\
\text { attempt is made to } \\
\text { consider their role } \\
\text { in analyzing } \\
\text { behavior of self or } \\
\text { others. }\end{array}$ & $\begin{array}{l}\text { Emotional reactions } \\
\text { are recognized, both } \\
\text { in the sense of } \\
\text { shaping ideas and in } \\
\text { considering how they } \\
\text { can frame the } \\
\text { account in different } \\
\text { ways. Reactions may } \\
\text { trigger or support a } \\
\text { change in } \\
\text { perspective. }\end{array}$ \\
\hline
\end{tabular}

\footnotetext{
${ }^{2}$ Adapted from the work of John Kleefeld \& Michaela Keet, University of Saskatchewan School of Law. Inspired by JENNIFER Moon, LeARning Journals: A HandBook for Reflective Practice and Professional DEVElopment (2d ed., 2006), and David Kember et al., A four-category scheme for coding and assessing the level of reflection in written work, 33 ASSESSMENT \& EVALUATION IN HighER EDUCATION 369 (2008). The categories here have been chosen to simplify and track a developmental continuum that can be used to characterize reflective analysis. The dimensions are distilled chiefly from Moon's work on learning journals for the professions.
} 
Appendix I. Assignments and Assessment (Justice Lawyering Seminar, Drexel University)

\begin{tabular}{|c|c|c|c|c|}
\hline $\begin{array}{l}\text { Reference } \\
\text { to literature } \\
\text { or theory }\end{array}$ & $\begin{array}{l}\text { There are no } \\
\text { references to } \\
\text { theory, or if there } \\
\text { are, they are } \\
\text { made without } \\
\text { apparently trying } \\
\text { to understand } \\
\text { them or form a } \\
\text { view on them. }\end{array}$ & $\begin{array}{l}\text { There is some } \\
\text { reference to } \\
\text { theory, with an } \\
\text { attempt to } \\
\text { understand it. } \\
\text { Concepts are } \\
\text { treated solely as } \\
\text { theory, without } \\
\text { being related to } \\
\text { personal } \\
\text { experiences or } \\
\text { practical } \\
\text { situations. }\end{array}$ & $\begin{array}{l}\text { There are } \\
\text { references to } \\
\text { theory, showing } \\
\text { both an } \\
\text { understanding and } \\
\text { an application of it. } \\
\text { Concepts are } \\
\text { interpreted in } \\
\text { relation to personal } \\
\text { experiences, or } \\
\text { situations en- } \\
\text { countered in } \\
\text { practice are } \\
\text { considered and } \\
\text { discussed in } \\
\text { relation to theory. }\end{array}$ & $\begin{array}{l}\text { There are references } \\
\text { to theory, showing } \\
\text { understanding and } \\
\text { application as well as } \\
\text { a questioning stance. } \\
\text { Theory helps to } \\
\text { trigger a } \\
\text { transformation of } \\
\text { perspective-a } \\
\text { review of } \\
\text { presuppositions from } \\
\text { prior conscious or } \\
\text { unconscious learning. }\end{array}$ \\
\hline $\begin{array}{l}\text { Reference to } \\
\text { experience or } \\
\text { future } \\
\text { practice }\end{array}$ & $\begin{array}{l}\text { There are no } \\
\text { references to prior } \\
\text { experience or } \\
\text { lessons to be } \\
\text { learned for future } \\
\text { practice. The } \\
\text { description may, } \\
\text { though, form a } \\
\text { basis for such } \\
\text { learning. }\end{array}$ & $\begin{array}{l}\text { There is some } \\
\text { attempt to } \\
\text { connect events } \\
\text { to prior } \\
\text { experience and a } \\
\text { sense that events } \\
\text { could lead to } \\
\text { lessons for future } \\
\text { practice. } \\
\text { However, the } \\
\text { reflection needs to } \\
\text { be deeper to } \\
\text { enable the } \\
\text { learning to begin } \\
\text { to occur. }\end{array}$ & $\begin{array}{l}\text { There are } \\
\text { references both } \\
\text { to prior } \\
\text { experience and } \\
\text { lessons for future } \\
\text { practice. There is } \\
\text { an attempt to use } \\
\text { events to analyze } \\
\text { progress in } \\
\text { attaining } \\
\text { learning goals. }\end{array}$ & $\begin{array}{l}\text { There is recognition } \\
\text { of how prior } \\
\text { experiences-of self } \\
\text { and others-influence } \\
\text { current behavior. } \\
\text { Points for learning are } \\
\text { noted and may be } \\
\text { revisited in later } \\
\text { accounts. The journal } \\
\text { shows growth over a } \\
\text { course of study. }\end{array}$ \\
\hline
\end{tabular}


Appendix II. Reflective report on Law Clinic case, University of Bourdeaux

\section{$\underline{\text { Reflexive report on Law Clinic case }}$}

The structure of this report is orientative. You can if you need use the structure of your choice

\section{SUMMARY}

Part 1: Law Clinic case: Description and Answer proposed

Part 2: Perception of this case

\section{- $\quad 2.1$ Cases’s difficulties}

- Technical and juridical difficulties

- Others difficulties (relation with client, with other colleagues, organization, etc.)

\section{- $\quad$ 2.2 Case's interests}

- Technical interest

- Social interest and or economical one

- Sociological interest

- Interest toward clients relations

- $\underline{\text { Others }}$

Part 3 : To go further / What do I learn from this case?

\section{- On the juridical level}

Is there a problem of source of law? What about fundamental rights? Is there a discrepancy between rule and reality? Is there any procedural problems? What about judiciary strategy? About the articulation with other legal disciplines?

\section{- On others aspects}

What do I learn on others disciplines (psychology, sociology, economics, philosophy, health and medicine, etc.)

Partie 4 : Personal feedback

Reflexive essay on an aspect of your law clinic experience. 
Appendix III. Observation grid for students visiting the prison (Legal Clinic Prison and Rights I, University of Turin)

\section{VISIT TO THE PRISON}

PRACTICAL NOTE:

Please remember that inside the prison it is not possible to bring mobile phones, bags, usb sticks: they must be left at the entrance. We also want to remind you to bring your identity card and be very punctual to respect the time of other people.

\section{OBSERVATION GRID \\ LEGAL CLINIC PRISON AND RIGHTS I - UNIVERSITY OF TURIN}

In order to better understand the penitentiary life conditions and the prisoners' legal needs, attention must be paid to some sensitive aspects during the visits to these institutions. The life inside the prison, in fact, is made up of relationships with people with different roles, of routines, of relationships, albeit mediated, with the outside world. Norms and practices regulate these aspects and we must keep them in mind when we move about within.

We ask you to read these points before the visit and keep them in mind.

In the evening or at the latest in the morning after your visit, (in order to have a "hot" reading) we ask you to answer and send the teacher the completed form: we remind you that the legal clinic works to the extent that each participant is committed to making it work.

Tutors can direct the next meeting on the more "critical" or less clear points identified through these grids. You will probably not be able to answer all the questions: do not worry. It is not an exam. We ask you to try to answer within the limits of what you have seen and heard. The aim of this tool is to offer you a grid in which to insert the many stimuli that you will receive and then help you to reflect in a "guided" way.

\section{METHODOLOGICAL NOTE}

Try to describe the path made during the visit in the prison, the modalities with which it was carried out, its duration, the operators encountered (paying particular attention to their respective roles and relationship dynamics), the relationships that have been established with the direction or with other operators, any difficulties encountered, the climate in which the visit took place.

\section{CHARACTERISTICS OF PRISON POPULATION}

What is the approximate percentage of foreign inmates, women, prisoners pending final sentence, or under special incarceration?

\section{TYPICAL DAY OF THE DETAINEES PERSON}

What is the temporal scan of a prisoner's typical day? How many hours can the prisoner spend outside his / her cell in social and outdoor spaces? Doing what? 
Special Issue: European Network for Clinical Legal Education $6^{\text {th }}$ Conference

Appendix III. Observation grid for students visiting the prison (Legal Clinic Prison and Rights I, University of Turin)

\section{COMPLAINTS}

What are the tools with which prisoners can communicate their requests to the prison management?

\section{TREATMENT ACTIVITIES AND SOCIAL REINTEGRATION}

Prisoners enjoy an individualized social reintegration project? How often the interviews with the educators and social workers are frequent?

\subsection{CULTURAL ACTIVITIES}

What are the main cultural and recreational activities organized within the institute? (This definition includes the sports activities that inmates can practice within the institution. Cultural activities also include the library service that must be present in all institutions and to which it is necessary to verify its use by the detained population and its degree of accessibility).

Is there a newspaper of prisoners (or similar initiatives)?

5.2 JOB

This theme involves two different issues: 1) What are the internal works of the institute directly managed by the prison administration; 2) What are the works contracted outside to private bodies?

\subsection{PROFESSIONAL TRAINING}

Are there any professional training courses? Professional training refers to those initiatives that seek to provide the detainees with professional knowledge that will allow them to be more easily reintegrated (or inserted) into the labor market.

\subsection{INSTRUCTION}

What are the school courses (of all types and levels) activated inside the prison? 
Special Issue: European Network for Clinical Legal Education $6^{\text {th }}$ Conference

Appendix IV. Individual report after meeting the client. Legal Clinic Prison and Rights I, University of Turin

INDIVIDUAL REPORT TO BE COMPLETED AFTER THE MEETING

Please give answer to these questions:

WHO IS HE/SHE? (Who did I deal with? Not the name, but the type of story of the person...)

HOW? (How did he/she relate to me/us? What impression did I have?)

WHAT? (What did he/she ask me directly? But what does he/she expect indirectly?)

WHY? (Why did he/she ask me this question?)

WHEN? (When does he/she expect my answer? Based on this data I have to give me deadlines: to study, to look for sources, to share with the group, with the teachers...) 